\title{
Comparison of serum calcium and magnesium between pre-eclampsia and normotensive pregnant women:a prospective study
}

\author{
Sah S. ${ }^{1}$, Goel J. K. ${ }^{2}$ \\ ${ }^{1}$ Dr. Shanti Sah, Assistant Professor, ${ }^{2}$ Dr. Jai Kishan Goel, Professor and Head of Department, both authors are attached with \\ Department of Obstetrics and Gyanecology, SRMS, IMS, Bareilly, UP, India.
}

Corresponding Author: Dr. Shanti Sah, Assistant Professor, Department of Obstetrics and Gyanecology, SRMS, IMS, Bareilly, UP, Email: shantisahmsog@gmail.com

\begin{abstract}
Background: A large percentage of maternal mortality is related to hypertensive disorders of pregnancy. The etiology of preeclampsia is uncertain with imbalance between vasoconstrictor and vasodilators leading to vasospasm and endothelial dysfunction. Magnesium and Calcium plays a role in vascular smooth muscle contraction and thus regulating blood pressure. Aim: We compared the serum level of Calcium and Magnesium of preeclamptic women with normotensive women at SRMS-IMS, Bareilly. Method: 30 preeclamptic patient between 18-35 years with BP $>140 / 90 \mathrm{mmHg}$ and gestation age $>30$ weeks were selected. Blood sample were taken for serum calcium and magnesium level and the results were compared with 20 normotensives pregnant. Result: Mean serum Calcium and Magnesium level in preeclamptic woman was $9.00 \pm 0.47$ and $1.90 \pm 0.31 \mathrm{mg} / \mathrm{dl}$, respectively. Mean serum Calcium and Magnesium in normal pregnant woman was $9.12 \pm 0.37$ and $1.92 \pm 0.23 \mathrm{mg} / \mathrm{dl}$, respectively. There was statistically no significant difference with $\mathrm{p}$ value of 0.34 and 1.00 , respectively. Conclusion: Serum Calcium and Magnesiumlevelwere observed to be same in preeclamptic and normotensive pregnant women.
\end{abstract}

Keywords: Preeclamptic, Normotensive, Serum Calcium, Serum Magnesium.

\section{Introduction}

Pregnancy is principally a phenomenon of maternal adaptation to increasing demands of growing fetus associated with progressive anatomical and physiological changes in all body system along with biochemical adaptation. Delivery of substance essential for fetal and placental growth, metabolism and waste removal is dependent on adequate perfusion of placental intervillous space brought by vascular refractoriness to pressure agents [1]. Preeclampsia is a pregnancy specific syndrome that can affect virtually every organ system [2].

Its incidence in India is $8-10 \%$. Hypertensive disorder including eclampsia accounts for $13-16 \%$ maternal mortality worldwide and $5 \%$ in India $[3,4]$. Etiology of preeclampsia is multifactorial associated with maternal maladaptation to cardiovascular or inflammatory changes along with abnormal trophoblastic invasion of uterine vessels or immunological maladaptation or related to genetic factor leading to intense vasospasm and endothelial cell injury [2]. During normal pregnancy there is a change in level of electrolytes and mineral

Manuscript received: $10^{\text {th }}$ June 2018

Reviewed: $20^{\text {th }}$ June 2018

Author Corrected: $27^{\text {th }}$ June 2018

Accepted for Publication: $29^{\text {th }}$ June 2018

Obsgyne Review: Journal of Obstetrics and Gynecology requirement, there is a decline in total serum calcium which follows reduction in plasma albumin concentration and also serum magnesium level declines [1]. Fluctuation in maternal serum ions maybe precipitating cause of elevated blood pressure in preeclampsia [5]. A study conducted by Dwivedi et al showed a reduced level of serum calcium and magnesium among women with preeclampsia in third trimester [6].

Dietary deficiency of magnesium has been established to play a role in blood pressure regulation and hence development of preeclampsia while Villar and co-workers showed that calcium supplementation is effective in decreasing perinatal mortality $[7,8]$.

Golmohammed et al found no difference in calcium and magnesium level in preeclamptic women compared to normotensive[9].

Thus role of serum calcium and magnesium in patient with preeclampsia remains uncertain.We therefore sought to compare serum calcium and magnesium level in preeclamptic and normal pregnant women.

Available online at: www.medresearch.in 29 | P a g e 


\section{Materials and Methods}

Place of study: Study was conducted in Obstetrics and Gynaecology department of rural tertiary care hospital in SRMS-IMS, Bareilly.

Sample size: Fifty (50) patients admitted with term pregnancy were included in study. Thirty (30) with raised blood pressure were enrolled under our study as cases and rest twenty (20) patients with normal blood pressure were termed as control.

Study design: Randomized controlled trial.

Inclusion criteria: All patients with term gestation with singleton pregnancy.

\section{Original Research Article}

Exclusion criteria: Following conditions which are likely to aggravatepre-eclampsiawere excluded for example:

a) Multiple pregnancies

b) Pregnancy with confounding risk factors like chronic hypertension, renal pathology.

c) Diabetes, anaemia or $\mathrm{Rh}$ isoimmunised pregnancy.

Sample collection: Data was obtained in a structured data sheet with variables of age, gestation age, parity, systolic and diastolic blood pressure, mean arterial pressure and BMI.4ml of venous blood sample was obtained in plain vial and sent to laboratory for analysis. Sample was centrifuged and serum calcium was measured by Arsenazo III method while serum magnesium was measured by Xylidyl blue method.

\section{Results}

In our study, majority of women were in age group of 21-25 years with period of gestation between 37-41 weeks

Table-1: Patient statistics.

\begin{tabular}{|c|c|c|c|}
\hline Variable & Control $(\mathbf{n}=\mathbf{2 0})$ & Cases $(\mathbf{P E})(\mathbf{n}=\mathbf{3 0})$ & P value \\
\hline Age (years) & $25.95 \pm 4.5$ & $27.3 \pm 5.02$ & - \\
\hline Gest. Age (weeks) & $38.2 \pm 1.6$ & $37.5 \pm 2.1$ & - \\
\hline SBP & $114.7 \pm 8.1$ & $153.2 \pm 11.37$ & - \\
\hline DBP & $74.6 \pm 5.69$ & $97.5 \pm 7.16$ & $<0.0001$ \\
\hline MAP & $87.94 \pm 5.61$ & $116.05 \pm 7.68$ & 0.0300 \\
\hline BMI & $24.44 \pm 3.63$ & $27.17 \pm 4.58$ & - \\
\hline
\end{tabular}

Value expressed as mean +/- SD; SBP- systolic blood pressure; DBP- diastolic blood pressure; MAP-mean arterial pressure; BMI-body mass index $\mathrm{MAP}=\{\mathrm{SBP}+(\mathrm{DBP} 2)\} / 3$

Table-2: Paritywise distribution

\begin{tabular}{|c|c|c|c|c|}
\hline \multirow{2}{*}{ Parity } & \multicolumn{2}{|c|}{ Normotensive } & \multicolumn{2}{c|}{ Preeclampsia } \\
\cline { 2 - 4 } & $\mathbf{n}$ & $\mathbf{0}$ & 17 \\
\hline G1 & 6 & 30 & 12 & 56.67 \\
\hline G2-G4 & 12 & 60 & 1 & 40 \\
\hline -G4 & 2 & 10 & 3.33 \\
\hline
\end{tabular}

$\mathrm{G}=$ Gravida

Maximum patient of preeclampsia were nullipara

Table-3: Comparison of mean calcium and magnesium in normotensive and pre eclamptic patients

\begin{tabular}{|c|c|c|c|c|c|c|}
\hline Variables & Normotensive & \multicolumn{4}{|c|}{ Pre-eclampsia (cases n=30) } & \multirow{2}{*}{ P value } \\
\cline { 3 - 6 } & $\begin{array}{c}\text { (control } \\
\text { n=20) }\end{array}$ & Mild (n=12) & $\begin{array}{c}\text { Severe } \\
(\mathbf{n = 1 8})\end{array}$ & P value & $\begin{array}{c}\text { Mean } \\
\text { (mild+severe) }\end{array}$ & \\
\hline s. $\mathrm{Ca}$ & $9.12 \pm 0.37$ & $9.13 \pm 0.42$ & $8.92 \pm 0.49$ & 0.31 & $9.00 \pm 0.47$ & 0.34 \\
\hline s. $\mathrm{Mg}$ & $1.92 \pm 0.23$ & $1.93 \pm 0.16$ & $1.88 \pm 0.38$ & 0.65 & $1.90 \pm 0.31$ & 1.00 \\
\hline $\mathrm{Ca} / \mathrm{Mg}$ & $4.81 \pm 0.75$ & $4.76 \pm 0.55$ & $4.76 \pm 0.86$ & 1.00 & $4.76 \pm 0.74$ & 0.81 \\
\hline
\end{tabular}

$\mathrm{P}$ value $<0.05$ significant $\mathrm{S}$. Ca- serum Calcium, S.Mg- serum magnesium $\mathrm{Ca} / \mathrm{Mg}$ - calcium: magnesium ratio 


\section{Original Research Article}

Mean serum calcium in preeclamptic patient was $9.00 \pm 0.47 \mathrm{mg} / \mathrm{dl}$ and $9.12 \pm 0.37 \mathrm{mg} / \mathrm{dl}$ in normotensive patient which was statistically not significant. No significant change in serum calcium was also observed between mild and severe preeclampsia with a $\mathrm{p}$ value of 0.31 .

Similarly serum magnesium level in normotensive women was $1.92 \pm 0.23 \mathrm{mg} / \mathrm{dl}$ against $1.90 \pm 0.31 \mathrm{mg} / \mathrm{dl}$ in $\mathrm{preeclamptic}$ which was also not significant statistically, even when compared between mild and severe preeclampsia.

Even the ratio of calcium: magnesium had no significant change between mild and severe preeclampsia or between preeclamptic and normotensive women.

\section{Discussion}

Preeclampsia occurs in $8-10 \%$ of pregnancies inIndia. Nulliparity is the most common feature of women who develops preeclampsia as most first pregnancy occurs in young women and most cases of preeclampsia or eclampsia occurs in this age group because of limited sperm exposure as concluded in study by Einarsson et al [10] and Sadat $Z$ et al[11].

Obesity is a risk factor for preclampsia, the incidence of preeclampsia increases with maternal BMI [12]. Even in women with normal weight, there is a linear relationship between prepregnant BMI and frequency of preeclampsia [13]. In our study the mean BMI of preeclamptic patient was $27.17 \pm 4.58$ and normotensive women was $24.44 \pm 3.63$ which was statistically significant ( $p$ value 0.03 ) and the finding was consistent with the study conducted by Kanagal et al [14] and Akhtar et al[15].

Serum calcium and magnesium are important cofactor for various enzymatic processesand water balance in cells [16]. These trace element plays an essential role in vascular smooth muscle tone and contraction, and hence are vital in blood pressure regulation [17]. Calcium and magnesium both act on smooth muscle and regulates blood pressure. Variety of calcium binding sites (eg. Troponin, parvalbumin, myosin and calmodulin) that plays a role in regulation of muscle contraction. Major effect of magnesium is to reduce the rate of calcium binding sites that bind magnesium and calcium competitively [18]. Lowering of serum calcium and increase of cellular calcium led to constriction of smooth muscle in blood vessel and increase of vascular resistance [19]. Magnesium plays a role in neurochemical transmission and peripheral vasodilatation and promotes vascular muscle relaxation [19,20].Magnesium deficiency through its lack of inhibition of calcium on smooth muscle produces increased peripheral resistance [21]. Magnesium lowers blood pressure by acting like natural calcium channel blocker, competes with sodium for binding site on vascular smooth muscles cells, increases PGE, binds to potassium in a cooperative manner and induces endothelial dependent vasodilatation and blood pressure reduction [22]. Magnesium act peripherally to produce peripheral vasodilatation by increasing the prostacyclin release from endothelial cell which act as a potent vasodilator and causes fall in blood pressure. Low level of magnesium predisposes to an increase in atrial pressure by increasing the vasoconstrictor effect of angiotensin II and noradrenalin [23].

A decrease in serum magnesium level as possible etiology of preeclampsia have been reported in various studies [24,25]. However Cochrane review did not found high quality evidence on dietary magnesium supplementation for prevention of preeclampsia [26]. Low serum calcium has been implicated as a cause of preeclampsia in some studies [14,27]. Stimulation of 1,25-dihydroxy cholecalciferol has been implicated in this vasoconstrictive mechanism [27]. Reduce calcium level increases release of parathyroid hormone and rennin which in turn causes increase intracellular calcium in vascular smooth muscle and sodium retension leading to increase vascular resistance and vasoconstriction leading to rise of blood pressure [27]. Magnesium is essential for release of PTH, mild magnesium deficiency increases PTH secretion and reduction in serum calcium causes increase in release of PTH and Renin causing increase intracellular calcium in smooth muscle leading to rise in blood pressure [28,27].

This concept of reduced serum calcium in preeclampsia is not universally accepted $[9,29]$. Some studies have shown reduced level of 1,25- dihydroxycholecalciferol in preeclamptic compared to normal pregnant women which increases parathyroid level causing calcium reabsorption from renal tubules and intestines causing no significant change in calcium level [19,20,30]. Therefore, hypocalcemia and hypomagnesemia as etiology of preeclampsia are not an universal finding [19,20,31].

Our study showed no significant change in serum calcium level between preeclamptic and normotensive women. Similar result were observed in study conducted by Ugwuja et al [32], Golmohhamed et al [9] and Adewoluet al [33]. A study by Ebenezer et al [5] also observed no significant change in calcium level which is consistent with our study. 
No significant change in serum magnesium level was observed in preeclampsia in our study which is consistent with studies conducted by PunthumapolC [20], Adewolu et al [33], Golmohhmed et al[9] and Ebenezer et al[5].

However other studies conducted by Kanagal DV et al[14], Akhtar S et al[15] showed a low level of calcium among preeclamptic women and low magnesium level were observed in studies conducted by Indumati et al [34] and Ugwuja et al[32]. In difference to our study low level of both serum calcium and magnesium in preeclamptic women was observed in studies conducted by Jain $\mathrm{S}$ etal [27] and Ephraim RKD et al[35].

\section{Conclusion}

Great emphasis of dietary calcium and magnesium has been shown by different studies but our study did not show any significant variation in serum calcium and magnesium level among preeclamptic and normotensive women. Our study being a very small study, larger trials are required to establish a definite correlation.

Acknowledgement: Author appreciated and thanks dept. of biochemistry and lab staff for their support in providing reports.

With this I also want to thank Dr. J.K.Goel for his proof reading.We are also grateful to all those authors whose articles are cited and included in references of this manuscript.

As per available researches till now, all studies are supporting administration of calcium supplementations in antenatal period, whereas contrary to the existing data we have found that there is no such role.

Ethical issues: The study was conducted after approval from ethical and protocol review committee of the institute.

\section{Funding: Nil, Conflict of interest: Nil Permission from IRB: Yes}

\section{References}

1. Cunningham FG. Maternalphysiology. In: Cunningham FG, Leveno KJ, Bloom SL, Haulti JC, Gilstre PL, Wenstrom KD, editors. Textbook of William obstetrics $24^{\text {th }}$ ed. New Yord: McGraw Hill;2014 pp 46-77.

2. Cunningham FG. Hypertensive disorder in pregnancy. In: Cunningham FG, Leveno KJ, Bloom SL, Haulti JC, Gilstre PL, Wenstrom KD, editor, Textboook of William obstetrics $24^{\text {th }}$ ed. New Yord: McGraw Hill; 2014 pp 728-779.

Obsgyne Review: Journal of Obstetrics and Gynecology

\section{Original Research Article}

3. Khan KS, Wojdyla D, Say L, et al. WHO analysis of causes of maternal death: a systematic review. doi: 10 . 1016/S0140-6736(06)68397-9.

4. Park K: Park's textbook of Preventive and Social Medicine: Preventive Medicine in obstetrics, paediatrics and Geriatrics-Indicator of $\mathrm{MCH}$ care; 24 ${ }^{\text {th }} \mathrm{ed}$; 2017: 592-598.

5. Owusu Darkwa E, Antwi-Boasiako C, Djagbletey R, et. al Serum magnesium and calcium in preeclampsia: a comparative study at the Korle-Bu Teaching Hospital, Ghana. doi: 10.2147/IBPC. S129106. eCollection 2017.

6. Dwivedi S, Bermen US, Sharma D: Mineral level in women with preeclampsia in third trimester of pregnancy. J. Clin Biomed Sci 2016;(6)1028-32.

7. Sarma P, Gambhir S. Theraputic uses of magnesium. Indian j Pharmacol. 2005; 27:7-13.

8. Villar J, Abdel-Aleem H, Merialdi M, et al. World Health Organization randomized trial of calcium supplementation among low calciumintake pregnant women. DOI:10.1016/j.ajog.2006.01.068

9. Golmohammed S, Amirabilou A, Yazadian M, Pashapour N. Evaluation of serum calcium, magnesium, copper and zinc levels in women with preeclampsia. Iran $\mathrm{J}$ Med Sci. 2008; 33(4): 231-234.

10. Einarsson JI, Sangi- Haghpeykar H, Gardner MO. Sperm exposure and development of preeclampsia. Am J Obstet Gynecol. 2003 May;188(5):1241-3.

11. Sadat Z, AbedzadehKalahroudi M, Saberi F. The effect of short duration sperm exposure on development of preeclampsia in primigravid women. Iran Red Crescent Med J. 2012 Jan;14(1):20-4. Epub 2012 Jan 1.

12. Stone JL, Lockwood CJ, Berkowitz GS, et al. Risk factors for severe preeclampsia. Obstet Gynecol. 1994 Mar; 83(3):357-61.

13. Bodnar LM, Ness RB, Markovic N, Roberts JM. The risk of preeclampsia rises with increasing prepregnancy body mass index. DOI:10. 1016/j.annepidem. 2004. 12. 008

14. Kanagal DV, Rajesh A, Rao K, et al. Levels of Serum Calcium and Magnesium in Pre-eclamptic and Normal Pregnancy: A Study from Coastal India. DOI:10. 7860 / JCDR / 2014/8872.4537

15. Akhtar S, Begum S, Ferdousi S. Calcium and Zinc deficiency in Preeclamptic women. J Bangldesh Soc Hysiol. 2011: 6(2): 94-9.

Available online at: www.medresearch.in 32 | P a g e 
16. Sissi C, Palumbo M. Effects of magnesium and related divalent metal ions in topoisomerase structure and function. doi: 10.1093/nar/gkp024. Epub 2009 Feb 2.

17. Walsh SB, Zdebik AA, Unwin RJ. Magnesium: The Disregarded Cation. doi: 10.1016/j.mayocp.2015.06.011.

18. Potter JD, Robertson SP, Johnson JD. Magnesium and the regulation of muscle contraction. Fed Proc. 1981 Oct; 40(12):2653-6.

19. Sukonpan K, Phupong V. Serum calcium and serum magnesium in normal and preeclamptic pregnancy. DOI:10.1007/s00404-004-0672-4

20. Punthumapol C, Kittichotpanich B. Serum calcium, magnesium and uric acid in preeclampsia and normal pregnancy. J Med Assoc Thai. 2008 Jul;91(7):968-73

21. Iseri LT, French JH. Magnesium: nature's physiologic calcium blocker. Am Heart J. 1984 Jul;108(1):188-93.

22. Houston MC, Harper KJ. Potassium, magnesium, and calcium: their role in both the cause and treatment of hypertension.vJ Clin Hypertens (Greenwich). 2008 Jul;10 (7 Suppl 2):3-11.

23. Resnick LM, Gupta RK, Gruenspan H, et al. Hypertension and peripheral insulin resistance. Possible mediating role of intracellular free magnesium. Am J Hypertens. 1990 May;3(5 Pt 1):373-9

24. Roberts JM, Myatt L, Spong CY, et al. Eunice Kennedy Shriver National Institute of Child Health and Human Development Maternal-Fetal Medicine Units Newyork. Vitamin $\mathrm{C}$ and $\mathrm{E}$ to prevent complication of pregnancy-associated hypertension. N Engl J Med.2010; 362 (14):1282-1291

25. Catov JM, Nohr EA, Bodnar LM, et al. Association of periconceptional multivitamin use with reduced risk of preeclampsia among normal-weight women in the Danish National Birth Cohort. DOI:10.1093/aje/kwp052

\section{Original Research Article}

26. Makrides M, Crosby DD, Bain E, Crowther CA. Magnesium supplementation in pregnancy. DOI:10.1002 / 14651858.CD000937.pub2

27. Jain S, Sharma P, Kulshreshtha S, et al. The role of calcium, magnesium, and zinc in pre-eclampsia. DOI:10. 1007/s12011-009-8423-9

28. Nutrition during pregnancy: Part I Weight gain: Part II Nutrient supplement. Washington (DC): National Academic Press (US);1990.15,trace element.

29. Levine RJ, Hauth JC, Curet LB, et al. Trial of calcium to prevent preeclampsia. DOI:10.1056/NEJM1997071033 70201

30. Hojo M, August P. Calcium Metabolism in Preeclampsia: Supplementation May Help. Medscape Womens Health. 1997 Jan;2(1):5.

31. Kumru S, Aydin S, Simsek M, et al.Comparison of serum copper, zinc, calcium, and magnesium levels in preeclamptic and healthy pregnant women. DOI:10. 1385/ BTER: 94:2:105

32. Ugwaja El, Famurewa AC, Ikaraho Cl. Comparison of Serum Calcium and Magnesium between Preeclamptic and Normotensive pregnant Nigerian women in Abakaliki Nigeria. Ann Med Health Sci Res.2016; 6(1): 33-37.

33. Adewolu OF. Serum sodium, potassium, calcium and magnesium in women with pregnancy induced hypertension and preeclampsia in Oredo local government Benin metropolis: A pilot study. Afr J Med Health Sci. $12: 1-5$

34. Bera S, Siuli RA, Gupta S, et al. Study of serum electrolytes in pregnancy induced hypertension. J Indian Med Assoc. 2011 Aug;109(8):546-8.

35. Ephraim RKD, Osakunor DNM, Denkyira SW et al. Serum calcium and magnesium level in women presenting with preeclampsia and pregnancy induced hypertension: a case control study in a cape coast metropolis, Ghana; BMC preg. and childbirth 2014, 14:390.

\section{How to cite this article?}

Sah S, Goel J. K. Comparison of serum calcium and magnesium between pre-eclampsia and normotensive pregnant women:a prospective study.Obs Rev:J obstet Gynecol 2018;4(2):29-33.doi: 10.17511/joog.2018.i02.02. 